\title{
California People of Faith against the Death Penalty
}

\author{
Jewish Community Center, La Jolla, October 16, 2001 \\ Episcopal Diocese, April 20, 2002
}

Rabbi Beerman remained to his last days an unrelenting opponent of capital punishment, a cause in which he joined the efforts of his friend the renowned actor Mike Farrell. The notion that the state would engage in what he called "premeditated and calculated murder" violated the core of his being. In articulating his opposition, Beerman drew deeply on Jewish legal norms. He noted that the Bible made reference to fifteen categories of capital offenses. But in good-and somewhat uncharacteristic rabbinic fashion-he pointed out that the Bible was not the last word in the matter. The rabbis of the Mishnah and Talmud, he observed, introduced a range of procedural rules intended to discourage, and even render impossible, the implementation of the death penalty. He quoted the medieval philosopher Maimonides' principle that a unanimous court judgment on capital punishment should be discounted because it rested on obvious bias. And he recognized that the State of Israel had formally forsworn capital punishment, with the singular exception of the execution of Nazi SS officer Adolf Eichmann in 1962. Beerman's revulsion at the practice led him to serve as a founding board member of Death Penalty Focus, a group established by Mike Farrell in 1988, at whose annual meetings the Los Angeles rabbi would regularly deliver a stirring benediction.

My friend, Mike Farrell, President of Death Penalty Focus, and one of the most impressive human beings I have ever met, once said: "It's only natural, on some level, to want to lash out at one who has inflicted pain on you. Like for like, I guess, is the root concept of ancient law. Blood for blood. If someone does ill to you, do it back to him in the belief that he will learn not to mess with you again. That's the guts theory of deterrence. So I absolutely understand the desire to strike out. If 
someone were to rape, brutalize or kill one of my loved ones I'd probably want to tear him apart with my bare hands, I'm sure. The question is whether or not one actually does it. In a civilized society, retribution is usually taken out of our hands and made subject to the courts.

"The idea of a legal system, someone once told me, is to remove emotion from the equation and allow reason and fairness to be applied so that understanding and ultimately justice can result. While I would be the first to admit that the equation is often perverted today, I think the intention is a noble one; to move us to a higher place, to help us as a people in society move farther away from the caves and closer to the stars."

In the early 190os, Upton Sinclair wrote a novel called The Jungle. His purpose in writing the book was to awaken people to the poverty and exploitation of those laboring in the stockyards of Chicago. It is said of his book that he aimed at the people's hearts, but instead hit their stomachs. Readers were revolted by his depiction of the slaughter of meat. So it was that the novel played an important role, not in improving the condition of the workers, but in the enactment of the first food and drug legislation of 1912.

Those of us who have been working for the abolition of capital punishment aimed at the hearts of our fellow Americans. We have tried to awaken their hearts to the realization that we are all bound together in a common humanity, that there is something inherently sacred in every human being, even in those who have committed the most bestial of crimes.

Then, we attempted to appeal to their reason, by challenging the idea of deterrence, by showing statistically that capital punishment does not deter. We have even tried to lure them by appealing to what sometimes appears to be the ultimate concern of all Americans, their pocketbooks. We were able to demonstrate that capital punishment is indeed more costly than life imprisonment without the possibility of parole.

But what may have at last loosened what appeared to be the fixed conviction of many Americans about the utter rightness of the death penalty is the appalling realization that in the last twenty-five years there were almost 650 executions, but that there were about 90 condemned persons who had convictions overturned by exonerating evidence. One out of seven. With the inescapable inference that some of the 650 executed were innocent. Conservatives in particular were taken with this revelation. For they realized that capital punishment, like the rest of the criminal justice system, is a government program. Always a reason to be skeptical. All of this is merely prelude to my subject for today-A Jewish Perspective on Capital Punishment.

Let us begin at the beginning, with words of Torah: From the book of Exodus"If men strive together ... and any harm follow, then shalt thou give life for life, eye for eye, tooth for tooth, burning for burning, wound for wound, stripe for stripe." 
And further on in the book of Leviticus: "Breach for breach, eye for eye, tooth for tooth. And he that hath maimed a man so shall it be done to him. And he that killeth a beast, shall make it good; and he that killeth a man shall be put to death. Ye shall have one manner of law as well for the stranger as for the home-born."

It is our Jewish heritage, which has given to the world the ancient law of retaliation-lex taliones. For fifteen different crimes the Bible prescribes capital punishment. Among the crimes punishable by death in the Torah-a rebellious son; trespass on sacred grounds; sorcery; bestiality; sacrifice to foreign gods; violating the Sabbath; adultery; incest; homosexuality; prostitution. And for thirty-six crimes, the whole body of Jewish legislation built upon the foundation of the Torah. But you must know that this is only the face of the Jewish law. For when Biblical law came to be translated into juridical practice, the ancient rabbis of the Talmud surrounded capital cases with so many restrictive prohibitions as [to] make it virtually impossible to enforce the death penalty. As early as the second century C.E., monetary damages had already replaced the literal words of the law, which inflicted upon the criminal the very injury he had caused. Although the ancient law, eye for eye, etc. seems barbaric, within its own historical context, it was not. It represented an advancement over the concept of limitless revenge. One eye, not two. One life, not that of an entire family, like the Hatfields and McCoys. Even so, it was a primitive form of justice. The ancient rabbis were uncomfortable with it, embarrassed by it. They insisted that in the case of bodily injury that the spirit of the Torah, not its literal word, should serve as a guide. They therefore substituted compensation in money, a principle of damages that we retain in our contemporary laws. But as for the crimes punishable by death, these were hedged in by a multitude of legal restrictions.

Jewish courts in Talmudic times differed from our modern custom. The first qualification applied to laws of evidence. According to the Bible, evidence is valid only if substantiated by two witnesses. Witnesses must have attained their majority, have never been accused of criminal offenses, cannot be related to the litigants, the judges, or to one another.

Another important qualification related to the acceptability of the confession of the accused. In a civil case if the defendant admits the charge, sentence is passed. But not so in a criminal case. The basic assumption is that a person does not belong to himself; just as one has no right to cause physical harm to another, so one has no right to inflict injury on himself. Therefore, the confession of a defendant has no legal validity. No man can be forced to incriminate himself; self-incrimination is unacceptable as evidence in court.

Nor is circumstantial evidence admissible. An extreme example is cited by the Talmud when it states that if witnesses see a man, sword in hand, pursuing someone, both entering a building, the pursuer emerges alone with a blood-stained weapon and the other is found dead inside, the pursuer cannot be convicted on 
the basis of this eye witness evidence. Witnesses can only attest to what they have actually seen with their own eyes.

Another important factor is clarification of the intentions of the defendant. A man cannot be sentenced to punishment unless he committed the deed with malice aforethought. How can you prove that? In most countries the law assumes premeditation on the basis of the actions of the criminal. Not so in ancient Jewish law. A person cannot be condemned to death unless witnesses attest not only to the crime but also to the fact that the defendant was warned (hatra'ah). That he was told before committing the crime that the act he was about to commit was punishable by death. It was necessary to verify that the defendant had taken note of it and accepted it by saying: "I know and I take it upon myself."

Unlike civil crimes, which were tried before a court of three, capital crimes were to be tried before a court of twenty-three qualified judges. Now in this court of twenty-three judges, a majority of one was sufficient to find for the accused, but a majority of three judges was necessary to declare the accused guilty. Even if the accused were found guilty, there were still regulations designed to protect against a miscarriage of justice. As he was being led to the place of execution, a herald would go forth calling out the name of the guilty one, proclaiming his crime, when and where it was committed, and the names of those upon the basis of whose testimony he had been condemned to death. The herald announced that anyone who possessed even a fragment of evidence favorable to the condemned man should hasten to produce it. Should anyone have produced such evidence, a stay of execution was granted. The final, and by our standards, certainly the most curious and enigmatic provision of the traditional law as interpreted by Maimonides (Mishna Torah IX, I) was the requirement that if there were a unanimous decision by the court of twenty-three finding the accused guilty, the accused would not be executed, for a unanimous court was presumed to be a prejudiced court.

Need any more be said to clarify the implications of these legal strictures, many of them so obviously impractical? Others may interpret the tradition differently, but the Talmud itself was able to state that a court which executed one murderer in seven or even seventy years was a "murderous court." Rabbi Akiba and Rabbi Tarfon, living in the second century, are recorded as saying that had they sat as judges, no accused person would ever have been subjected to the death penalty.

So this opposition to the death penalty is what we must draw from Jewish tradition. And it must have been with this aspect of the spirit of Judaism in mind that the laws of the State of Israel specifically eliminated capital punishment. Israel made an exception in the Genocide Law it enacted in 1950, the law relating to the crimes of the Nazis and their collaborators. Under this law, crimes committed in the years 1933 to 1945, crimes against humanity and against the Jewish people, were liable to the death penalty. It was this exception, which permitted Adolf Eichmann to be tried, found guilty, and then executed in 1961 for "Crimes against the Jewish 
people" and "for causing the killing of millions of Jews." Despite onslaughts of terrorists in Israel, Eichmann is still the only person to be executed. I suppose if we executed only those who have killed defenseless millions, there would be far less debate about capital punishment.

It shouldn't surprise us that virtually every major Jewish organization has called for the abolition of the death penalty in America-The American Jewish Committee, the American Jewish Congress, the Central Conference of American Rabbis, the UAHC, etc.

Execution is not simply death. It is premeditated and calculated murder. For there to be an equivalency between the death penalty and murder, execution would, in the words of Albert Camus, have to "punish a criminal who had warned his victim of the date at which he would inflict death upon him, and who, from that moment onward, had confined him at his mercy for months." Such a monster is not encountered in private life.

We are responsible for how we punish. We can punish to educate, to improve, to seek, to redeem. We can punish to deter, to exact retribution, to protect. But to punish out of revenge, it seems to me, turns us into thugs.

\section{COMMENTARY BY MIKE FARRELL}

Leonard was a "resister." As he put it in another context, "To be most deeply human is to be among the resisters, to resist whatever demeans life." Keenly aware of the "terrible fragility" of our human condition, he believed we know intuitively "that there is in every human being the possibility of what is humane" and he saw that in "every moment we are given the opportunity to transform the human situation."

In this speech Leonard used his deep understanding of Jewish history, the Torah, and the Talmud to illustrate the fact that despite clear biblical assertions that death is the appropriate punishment for certain crimes, there is a deeply embedded human instinct that argues otherwise.

Positing here a "Jewish Perspective on Capital Punishment," he traces the torturous path of the ancient rabbis in which they "surrounded capital cases with so many restrictive prohibitions as [to] make it virtually impossible" to carry out. They were, he insists, "uncomfortable with it, embarrassed by it."

Tracing developments in legal and juridical thought through the centuries, Leonard here carefully demonstrates that the laws regulating the behavior of human beings, even as we labor to honor the demands and assertions of the ancients, must inevitably respond to the respect for life fundamental to human existence.

Given "the fragile brevity of life and love," he would argue, nothing in law or the requirement of order can overcome the fact that "we were all meant for a great common tenderness." 